\title{
Lead-Tolerant Bacteria Can Minimize Lead Toxicity in Plants
}

\author{
Tehreem Aslam and Ambreen Ahmed* \\ Department of Botany, University of the Punjab, Quaid-e-Azam Campus, Lahore 54590, Pakistan
}

\section{ABSTRACT}

In today's world, environment is exposed to lead due to various anthropogenic activities. It adversely affects plants as well as microorganisms by disturbing soil health and fertility. Bioremediation is a technique used to sequester heavy metals from the contaminated soil and it can be used to decontaminate the polluted soil. Lead-tolerant plant health promoting rhizobacteria (PHPR) can be used to enhance the efficacy of lead remediation. Lead uptake can be enhanced through bacteria by modifying root structure, secreting metal sequestering molecules in rhizosphere and alleviating lead induced phytotoxicity. For this purpose, lead-resistant auxin-producing bacteria were isolated from the rhizosphere of some plants. These auxin-producing lead-tolerant bacteria were used to treat Zea mays both in the presence and absence of lead-stress under laboratory conditions and its impact on plant growth and biochemical parameters of Zea mays were analysed.

Keywords:
Bioremediation, Lead, PGPR, Zea mays, PMI.

Article info.

Received: April 23, 2018

Accepted: June 25, 2018

Conflict of Interest: Nil

\section{INTRODUCTION}

Increasing global population has lead to increase in industrialization, technological developments and overuse of natural resources and release of contaminants into the environment which in turn resulted in greater number of highly polluted areas. Increasing demands of land for housing, infrastructure and recreation reduced the feeling to remediate polluted areas.

Heavy metals contamination poses a serious threat to plants and animals throughout the whole world. Due to their sustainability, they pose a serious threat to agricultural fields ${ }^{1}$. Excess of heavy metals are absorbed by roots which accumulate in various plant organs and reduce growth by disturbing metabolic processes ${ }^{2}$. Thus, soil re-establishment processes are essential for reinvesting in agricultural production. Bioremediation is a promising technology which involves environmental friendly processes for remediation of polluted soil and water on a large scale ${ }^{3,4}$. The advancement of bioremediation strategies, such as the associations of bacteria with the plants rhizosphere that grow in contaminated soils are important because of the biotechnological capability of microorganisms for metal elimination directly from soil or the expected transport of metals to the plants ${ }^{5}$. Lead is among one of the most abundant and widespread heavy metals in the environment. Paints, mining sites, gasoline, explosives, paper and pulp industries and municipal sewage are the major causes of its release in the atmosphere ${ }^{1,4}$.

Plant growth is enhanced by bacteria that grow in the rhizosphere which are termed as PGPR ${ }^{6}$. Several studies have investigated that the potential of plants to separate heavy metals from soil is improved by plant growth 
hormones ${ }^{7,8}$. Plants follow specific growth patterns which are resolved and managed by phytohormones ${ }^{9}$. Auxins play an important role in the plant growth promoting ability of rhizobacteria ${ }^{6}$. Bacterial auxins act as signaling molecules and strengthen bacteria - plant relationship. The most significant attributes of plants inoculated with auxin-producing plant growth enhancing bacteria is the alteration in the root structure and growth ${ }^{10}$. The utilization of PGPB in phytoremediation is also termed as PGPB enhanced phytoremediation (PEP) which is considered as a cheaper eco-friendly technique to increase plant stress tolerance, biomass productivity and bioremediation effectiveness during reclamation of polluted lands.

Some of the lead-tolerant Zea mays varieties have been reported. Lead mostly accumulates in the root and shoots of Zea mays plant, which are not eaten as food. So, chances of lead consumption and its addition into the food chain have reduced.

\section{MATERIALS AND METHODS}

\section{Bacterial Strains and MIC}

Six lead-resistant bacterial strains i.e., Bacillus anthracis (P1iv), Bacillus sp. (T4b), Sporosarcina sp. (T8bi), Bacillus cereus (S4ii), Bacillus cereus (T10ai) and T2aii were utilized for the present study. The bacterial strains were cultured at $37^{\circ} \mathrm{C}$ using L-agar supplemented with various concentrations of lead overnight to know the minimum inhibitory concentration of lead and growth of strains was recorded.

\section{Biological Assay}

Zea mays certified seeds of variety DK-6142 were taken from the Punjab Seed Corporation, Lahore, Pakistan. Autoclaved petriplates $(120 \mathrm{~mm})$ were taken. Two Whatman filter paper no. 1 were adjusted in each plate. Plates were labeled with different bacterial strains and lead stress as well. Seeds of Zea mays were washed with $0.1 \% \mathrm{HgCl}_{2}$ for 2-3 minutes followed by several washings with autoclaved distilled water. Zea mays seeds were dipped in bacterial inoculum. Seeds were then placed on the filter paper aseptically and different concentrations of lead solution were added i.e., 0, 400, 800 and $1200 \mu \mathrm{g} / \mathrm{ml}$. All petriplates were kept in dark. Root length, number of primary as well as secondary roots of the seedlings were noted after one week.

\section{Plant-Microbe Interaction}

Petriplates of $120 \mathrm{~mm}$ diameter were subjected to washing and drying before use. Two layers of Whatman filter paper no. 1 were placed in each plate then plates were autoclaved. The autoclaved plates were oven dried. Plates were properly labeled for each strain and control (without inoculation) with different concentrations of working solution of lead nitrate $\left(\mathrm{PbNO}_{3}\right)$ i.e., $0 \mu \mathrm{g} / \mathrm{ml}$ (control treatment), 400, 800, 1200, and $1600 \mu \mathrm{g} / \mathrm{ml} .10 \mathrm{ml}$ of sterilized salt solution with various concentrations $(0$, 400,800 and $1200 \mu \mathrm{g} / \mathrm{ml}$ ) were added to each respective treatment. Inoculated and treated Zea mays (var. DK6142) seeds were placed on the moistened filter paper in the petriplate which were placed for three days in dark condition at $25 \pm 2{ }^{\circ} \mathrm{C}$. After three days, five germinated seedlings were sown in the labeled pots each with 140 gm sieved soil and lead stress solutions with 0,400, 800 and $1200 \mu \mathrm{g} / \mathrm{ml}$ of lead nitrate $\left(\mathrm{PbNO}_{3}\right)$ was added to the respective pots. The light period of $10 \mathrm{Klux}$, for 16 hours duration was provided to the plants at $25 \pm 2{ }^{\circ} \mathrm{C}$. Seedlings were grown for $20-25$ days and then the growth of the inoculated and non-inoculated treatments was analysed by observing shoot length, root length, fresh wt. and number of leaves. Protein test ${ }^{11}$ and auxin test ${ }^{12}$ for the inoculated and non- inoculated plants were also performed. The experiment was repeated thrice.

\section{RESULTS}

\section{Biological Assay}

Inoculation with the bacterial strain T2aii caused increment in the root length upto $358.3 \%$ in the absence of lead stress. The strain Bacillus cereus S4ii (20\%) caused maximum increase in the number of primary roots without the addition of lead stress. Under the lead stress of 400 and $800 \mu \mathrm{g} / \mathrm{ml}$, maximum enhancement upto 55.5 and $75 \%$ respectively, was recorded in the number of primary roots of seedlings inoculated with the bacterial strain Bacillus sp. (T4b) over control treatments. In the presence of lead stress of $1200 \mu \mathrm{g} / \mathrm{ml}$, inoculation with the bacterial strain Bacillus anthracis (P1iv) showed high reduction $(80 \%)$ in the number of primary roots as compared to control. The number of secondary roots were enhanced by inoculation of seedlings by the bacterial strains Bacillus cereus (S4ii), Bacillus cereus (T10ai) and T2aii upto 193, 186 and $176 \%$, respectively in comparison 
to control. Under the lead stress of 400,800 and $1200 \mu \mathrm{g} / \mathrm{ml}$, maximum increment in the number of secondary roots i.e., 335,352 and $160.5 \%$ respectively, was exhibited by inoculation with the bacterial strain Sporosarcina sp. (T8bi) when compared with control plants (Fig. 1).

\section{Plant-Microbe Interaction}

The germination percentage was not affected by bacterial treatment of seeds both in the presence and absence of lead stress. Treatment of seeds with the bacterial strains Bacillus cereus (T10ai), Bacillus cereus (S4ii) and Sporosarcina sp. (T8bi) showed enhancement upto 6.2, 5.7 and $5.3 \%$, respectively, in the shoot length in the absence of lead stress. Although, shoot length was enhanced by inoculation of seeds with the bacterial strains under the lead stress $(400-1200 \mu \mathrm{g} / \mathrm{ml})$ but treatment of seeds with the bacterial strain Bacillus cereus (S4ii) showed maximum increase of 13.5, 28.8 and $19.6 \%$, respectively, in comparison to the respective control. Treatment of seeds with the bacterial strains T2aii, Bacillus cereus (S4ii) and Bacillus sp. (T4b) exhibited increment in the root length of plants i.e., 40.9, 29.2 and $28.4 \%$, respectively, without the addition of lead stress. Under the lead stress of 400,800 and $1200 \mu \mathrm{g} / \mathrm{ml}$, increment of $8.9,19.7$ and $8.5 \%$ in root length was recorded by inoculation of seeds with the bacterial strain Sporosarcina sp. (T8bi), as compared to non-inoculated lead stressed control plants. Inoculation of plants with the strain S4ii showed reduction of 13,17 and $4.2 \%$ in the root length as compared to control treatments (Fig. 2). In the absence of lead stress, treatment of seeds with the bacterial strains Bacillus cereus (S4ii), Bacillus cereus (T10ai) and Sporosarcina sp. (T8bi) exhibited increment in the number of leaves when compared with control treatments. Number of leaves was not much affected by treatment with the lead stress of 400 and $800 \mu \mathrm{g} / \mathrm{ml}$. Lead stress of $800 \mu \mathrm{g} / \mathrm{ml}$ showed enhancement in number of leaves by inoculation with all the strains and inoculation with the strains Bacillus anthracis (P1iv), Bacillus cereus
(S4ii) and Bacillus sp. (T4b) caused maximum increment upto $41.2 \%$ over control (Fig. 3). Although, lead stress did not decrease the number of leaves significantly but the leaves showed chlorosis and tip burns under lead stress which was more prominent in non-inoculated plants compared to inoculated treatments under lead stress. Fresh weight of plants was enhanced by inoculation with bacterial strains both in the presence and absence of lead stress. Plants treated with the strain Bacillus cereus (S4ii) caused enhancement i.e., 39\% in fresh weight without the addition of lead stress as compared to control. Under the lead stress of 400,800 and $1200 \mu \mathrm{g} / \mathrm{ml}$, enhancement of $107.8,76.7$ and $13.5 \%$ respectively, was exhibited by treatment with the bacterial strain Bacillus cereus (S4ii) as compared to non-inoculated control treatments. Protein content of plants was reduced by inoculation of seeds with all the bacterial strains (P1iv, S4ii, T10ai, T8bi, T2aii and T4b). Maximum reduction of $70.7 \%$ was recorded by inoculation with the bacterial strain T2aii without the addition of lead stress. Inoculation of seeds with the bacterial strain T2aii also exhibited reduction (29.5, 62.9 and $10.4 \%$, respectively) in protein content under different lead stresses i.e., 400,800 and $1200 \mu \mathrm{g} / \mathrm{ml}$ in comparison to respective control. But, lead stress of $1200 \mu \mathrm{g} / \mathrm{ml}$ showed enhancement in plants inoculated with the strain T10ai which showed highest increment of $209.8 \%$ in the protein content when compared with control. Auxin content showed highest increment upto $30.8 \%$ by inoculation of seeds with the bacterial strain Bacillus cereus (T10ai) as compared to control plants. Under the lead stress of $400 \mu \mathrm{g} / \mathrm{ml}$, auxin content was reduced in all inoculated plants. Treatment of seeds with the bacterial strains Bacillus cereus (T10ai) and T2aii showed maximum reduction i.e., $52 \%$ in the auxin content over respective control. In the presence of lead stress of 800 and $1200 \mu \mathrm{g} / \mathrm{ml}$, increment of 22 and $16 \%$ was exhibited in auxin content with the bacterial inoculation of Sporosarcina sp. (T8bi) as compared to respective noninoculated control treatments (Fig. 4). 


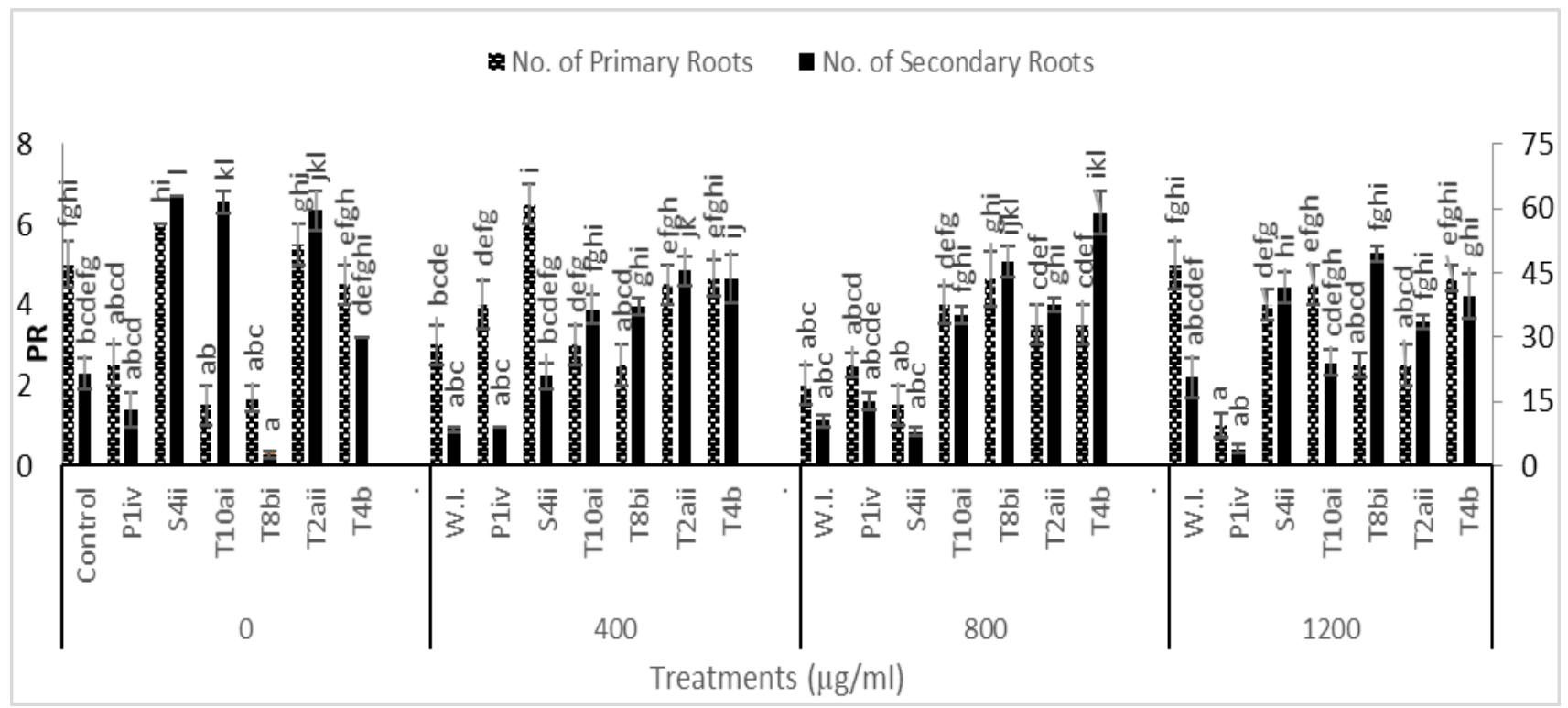

Fig. 1: Influence of bacterial treatments in the presence and absence of lead stress $\left[\left(\mathrm{PbNO}_{3}(\mu \mathrm{g} / \mathrm{ml})\right]\right.$ on primary and secondary roots number of Zea mays in laboratory experiment. [W.I. = without bacterial inoculation; Bacterial strains = P1iv, S4ii, T10ai, T8bi, T2aii and T4b]. Data shows mean of fifteen replicates. Different letters designate significant difference between treatments using Duncan's multiple range test $(P=0.05)$.

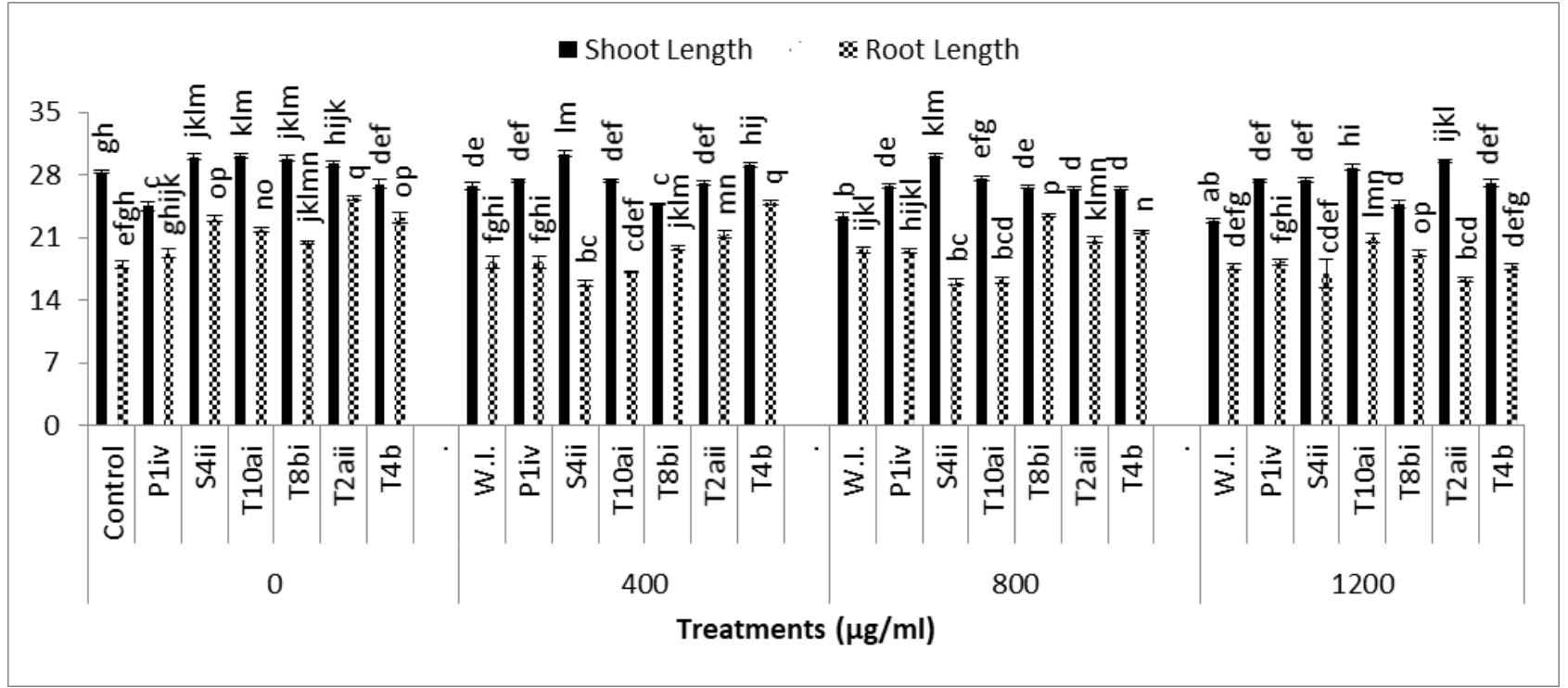

Fig. 2: Influence of bacterial treatments in the presence and absence of lead stress $\left[\left(\mathrm{PbNO}_{3}(\mu \mathrm{g} / \mathrm{ml})\right]\right.$ on shoot length $(\mathrm{cm})$ and root length $(\mathrm{cm})$ of Zea mays in laboratory conditions. [W.I. = without bacterial inoculation; Bacterial isolates = P1iv, S4ii, T10ai, T8bi, T2aii and T4b]. Data represent mean of fifteen replicates. Different letters designate significant difference between treatments using Duncan's multiple range test $(P=0.05)$. 


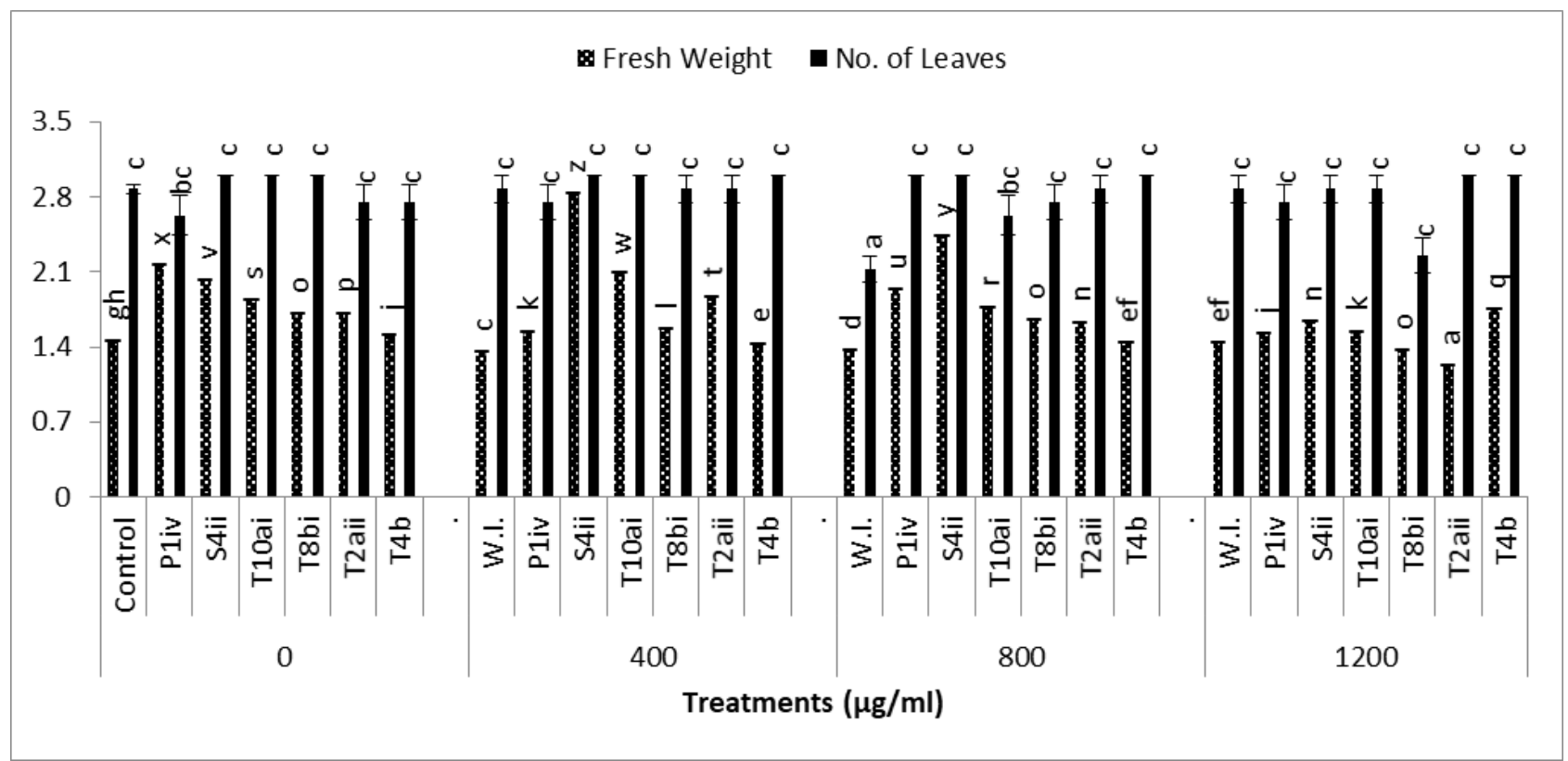

Fig. 3: Influence of bacterial treatments in the presence and absence of lead stress $\left[\left(\mathrm{PbNO}_{3}(\mu \mathrm{g} / \mathrm{ml})\right]\right.$ on fresh weight $(\mathrm{g})$ and leaves number of Zea mays in laboratory conditions [W.I. = without bacterial inoculation; Bacterial isolates = P1iv, S4ii, T10ai, T8bi, T2aii and T4b]. Data represent mean of fifteen replicates. Different letters designate significant difference between treatments using Duncan's multiple range test $(P=0.05)$.

Protein Test a Auxin Test

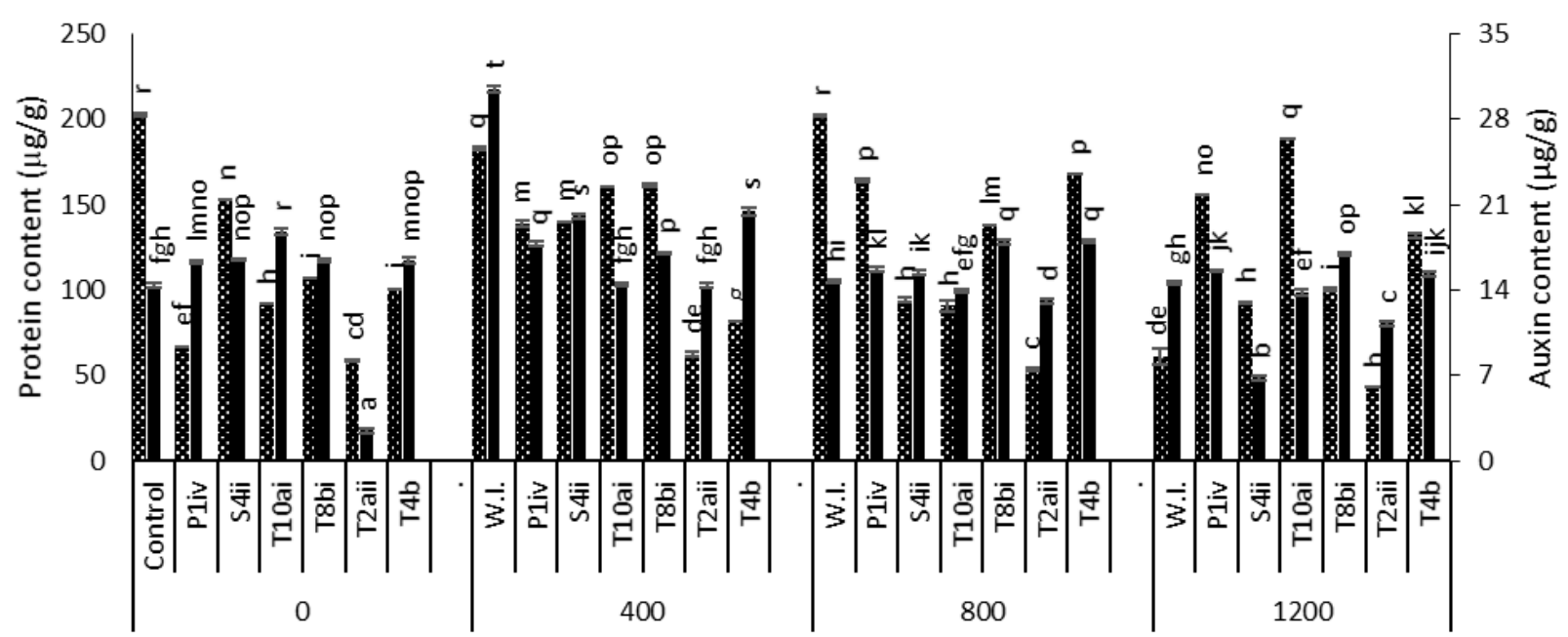

Treatments

Fig. 4: Influence of bacterial treatments in the presence and absence of lead stress $\left[\left(\mathrm{PbNO}_{3}(\mu \mathrm{g} / \mathrm{ml})\right]\right.$ on protein and auxin concentration of Zea mays under laboratory conditions. [W.I. = without bacterial inoculation; Bacterial isolates = P1iv, S4ii, T10ai, T8bi, T2aii and T4b]. Data represent mean of fifteen replicates. Different letters designate significant difference between treatments using Duncan's multiple range test $(P=0.05)$. 


\section{DISCUSSION}

The current research deals with the study of bacterial treatment of Zea mays for reducing hazardous impact of lead on plant growth and development under lead stress. The biological assay was conducted to study the effect of auxin-producing bacteria on the growth of Zea mays in the presence and absence of various lead concentrations $(0,400,800$ and $1200 \mu \mathrm{g} / \mathrm{ml})$. Root length, number of primary roots and number of secondary roots were enhanced by inoculation of seeds with the bacterial strains Bacillus cereus (S4ii) and T2aii in the absence of lead stress while inoculation with the strain Sporosarcina sp. (T8bi) showed reduction when compared with control treatment.

The selected six auxin producing lead-resistant bacterial strains were used to assess their plant health promoting potential under lead stress for which seeds of Zea mays variety DK-6142 were inoculated with the selected auxinproducing lead resistant bacterial strains in the presence of lead stress. Inoculation with the bacterial strain Bacillus cereus (S4ii) caused prominent increment in growth parameters like shoot length, germination percentage, root length, fresh weight, number of leaves, and auxin content of Zea mays in the absence of lead stress in comparison to control. Under the lead concentration of $400 \mu \mathrm{g} / \mathrm{ml}$, the germination percentage was decreased in inoculated plants whereas lead stresses of 800 and $1200 \mu \mathrm{g} / \mathrm{ml}$ does not affect germination percentage of plants treated with various bacterial strains as compared to respective control treatments. The shoot length of plants inoculated with the bacterial strains Bacillus anthracis (P1iv), Bacillus cereus (S4ii), T10ai, T8bi and Bacillus sp. (T4b) showed enhancements under the lead stresses of 400,800 and $1200 \mu \mathrm{g} / \mathrm{ml}$ as compared to control. Similarly, Hassan et al. ${ }^{13}$ have reported increment in the height (shoot length) of wheat by inoculation with Pseudomonas moraviensis and Bacillus cereus upto $32 \%$. The increment in plant height in the presence of PGPR is attributed to increase IAA synthesis that improve cell elongation and cell division ${ }^{13}$. Under various lead stresses $(400-1200 \mu \mathrm{g} / \mathrm{ml})$, treatment with the bacterial strain T8bi caused increment in root length over control treatments while inoculation with the bacterial strain Bacillus cereus (S4ii) caused reduction in root length under the different lead stresses i.e., 400,800 and $1200 \mu \mathrm{g} / \mathrm{ml}$ when compared with the respective control treatments. Likewise, Cathrine and $\mathrm{Navab}^{3}$ stated that lead accumulate more rapidly in the roots as compared to shoots. So, the roots of Lepidium sativum $L$. are much more sensitive to phytoremediation of lead than the shoots. Number of leaves showed no significant effect by inoculation with bacterial strains under lead stress of 400 and $1200 \mu \mathrm{g} / \mathrm{ml}$ but inoculation of seeds with the bacterial strains enhanced the number of leaves under the lead stress of $800 \mu \mathrm{g} / \mathrm{ml}$ as compared to control. Although lead stress has shown negligible effect on the number of leaves but increasing lead stress caused chlorosis of leaves indicating the toxic effect of lead on photosynthetic pigments. So, leaves were not healthy and chlorosis of the leaves suggest that the overall biology of the plants was adversely affected by increasing lead stress. Idicko and Verma ${ }^{14}$ have reported increment in number of leaves of inoculated maize plants as compared to control. The Pseudomonas sp. improved the number of leaves up to $8 \%$ whereas Azotobacter sp. increased the leaves number upto $7.67 \%$ as compared to the non-treated plants. Under the lead stress of 400 and $800 \mu \mathrm{g} / \mathrm{ml}$, the fresh weight of plants inoculated with all the bacterial strains i.e., P1iv, S4ii, T10ai, T8bi, T2aii and T4b showed enhancements as compared to the non-inoculated lead stressed plants. The lead stress of $1200 \mu \mathrm{g} / \mathrm{ml}$ exhibited enhancement in fresh weight by plants inoculated with all the bacterial strains (Bacillus anthracis P1iv, Bacillus cereus S4ii, T10ai, T2aii and Bacillus sp. T4b) except plants inoculated with the strain Sporosarcina sp. (T8bi) in comparison to control. Similar results were obtained showing increment in fresh weight of groundnut plant inoculated with bacterial strains at various stages of its growth as compared to control ${ }^{15}$. The protein concentration of Zea mays plants treated with all the bacterial strains showed enhancements under the lead stress of 400 and $800 \mu \mathrm{g} / \mathrm{ml}$ whereas the lead stress of $1200 \mu \mathrm{g} / \mathrm{ml}$ exhibited enhancements in the protein content of all the inoculated plants except plants treated with the bacterial strain T2aii when compared with the respective non-stressed treatments. Reduction in protein production is an essential biochemical demonstration of lead toxicity which is showed by others also, such as Bano et al. ${ }^{16}$ have also reported that instead of the reports of stress 
protein synthesis, the protein content generally decreases due to stress as the rate of photosynthesis declines due to unavailability of raw material for protein production which leads to the reduction or complete cessation of the process. The increase in protein degradation as compared to their production can also be the reason of reduction in protein content ${ }^{16}$. Reduction in auxin content of inoculated plants was observed under the lead stress of $400 \mu \mathrm{g} / \mathrm{ml}$ over the control treatment. In the presence of lead stress of 800 and $1200 \mu \mathrm{g} / \mathrm{ml}$, treatment of plants with the bacterial strains, Sporosarcina sp. T8bi Bacillus anthracis P1iv and Bacillus sp. T4b showed enhancements in auxin content when compared with the control. According to Zhu et al. ${ }^{17}$, auxin production showed negative association with zinc concentration under the influence of PGPR isolates. By increasing zinc concentration, the auxin production must be decreased by bacterial isolates due to reduction in root growth of wheat plant under zinc stress ${ }^{17}$. They also observed that instead of reducing the auxin synthesis under zinc stress, bacterial isolates exhibit metal transport from roots to shoots and retarded the zinc accumulation in the $\operatorname{root}^{17}$ so a similar relationship may exist between some of the bacterial isolates and lead stress which caused reduction in the auxin content.

\section{CONCLUSION}

Thus the current study suggests that lead stress adversely affects the photosynthetic pigments in plants leading to chlorosis in the leaves under lead stress which results in poor plant growth. Treatment with lead-tolerant bacterial isolates improve plant growth under lead stress and thus can be effectively applied in lead-contaminated areas for plant growth improvement.

\section{REFERENCES}

1. Singh N, Yadav A, Varma A. Effect of plant growth promoting activity of rhizobacteria on cluster bean (Cyamopsis Tetragonoloba L.) plant growth and biochemical constituents. Int J Agri Res. 2015; 4(5): 1071-82.

2. Ahsan MT, Najam-ul-haq M, Idrees M, Ullah I, Afzal M. Bacterial endophytes enhance phytostabilization in soils contaminated with uranium and lead. Int J Phyto. 2017; 19(10): 937-46.

3. Cathrine LF, Navab M. Soil decontamination using garden cress. J Sci Res Develop. 2014; 1 (1): 1-6.
4. Ahmad I, Akhtar MJ, Mehmood S, Akhter K, Tahir M, Saeed MF, et al. Combined application of compost and Bacillus sp. CIK-512 ameliorated the lead toxicity in radish by regulating the homeostasis of antioxidants and lead. Ecotoxicol Environ Safety. 2018; 148: 805-12.

5. Fatnassi IC, Chiboub M, Saadani O, Jebara M, Jebara $\mathrm{SH}$. Impact of dual inoculation with rhizobium and PGPR on growth and antioxidant status of Vicia Faba $L$. under copper stress. C R Biol. 2015; 338: 241-54.

6. Lamont BB, Fernández MP, Sanchez JR. Soil bacteria hold the key to root cluster formation. New Phytol. 2014; 206(3):1156-62.

7. Chouychai $W$, Kruatrachue $M$, Lee $H$. Effect of plant growth regulators on phytoremediation of hexachlorocyclohexane contaminated soil. Int J Phytoremed. 2015; doi: 10.1080/15226514.2014.989309

8. Sobariu DL, Fertu DLT, Diaconu M, Pavel LV, Hlihor R, Drăgoi EN, et al. Rhizobacteria and plant symbiosis in heavy metal uptake and its implications for soil bioremediation. New Biotechnol. 2017; 39: 125-34.

9. Peleg Z, Blumwald E. Hormone balance and abiotic stress tolerance in crop plants, Curr Opin Plant Biol. 2011; 14: 290-5.

10. Ahmed A, Hasnain $S$. Auxins as one of the factors of plant growth improvement by plant growth promoting rhizobacteria. Pol J Microbiol. 2014; 63 (3): 261-6.

11. Lowry $\mathrm{OH}$, Resebrough NJ, Farr AL. Protein measurement with the folin-phenol reagent. J Biol Chem. 1951; 193: 265.

12. Mahadevan A. In: Growth regulators, Microorganisms and diseased plants. Oxford and IBH Publishing Company, India .1984.

13. Hasan M, Bano A, Hassan SG, lqbal J, Awan U, Rong-Ji $\mathrm{D}$, et al. Enhancement of rice growth and production of growth-promoting phytohormones by inoculation with rhizobium and other rhizobacteria. World Appl Sci J. 2014; 31 (10): 1734-43.

14. Idicko AH, Verma RK. Effect of growth promoting microbes on initial growth of Maize. Ind J Trop Biodiver. 2014; 22(1): 64-9.

15. Mathivanan $S$, Chidambaram ALA, Sundramoorthy $P$, Baskaran L, Kalaikandhan R. Effect of combined inoculations of plant growth promoting rhizobacteria (pgpr) on the growth and yield of groundnut (Arachis Hypogaea L.). Int J Curr Microbiol Appl Sci. 2014; 3(8): 1010-20.

16. Bano Q, llyas N., Bano A, Zafar N, Akram A, Hassan F. Effect of Azospirillum inoculation on Maize (Zea Mays L.) under drought stress. Pak J Bot. 2013; 45(S1): 13-2.

17. Zhu D, Ouyang $L, X u Z$, Zhang L. Rhizobacteria of Populus euphratica promoting plant growth against heavy metals. Int J Phytoremed. 2015; 17(10): 973-80. 